\title{
A step by step approach in differential diagnosing of adrenal incidentaloma (epinephroma), (with comments on the new Clinical Practice Guidelines of the European Society of Endocrinology)
}

\author{
FREDERICK-ANTHONY FARRUGIA ${ }^{1}$, EVANGELOS MISIAKOS ${ }^{2}$, GEORGIOS MARTIKOS ${ }^{2}$, PANAGIOTIS TZANETIS ${ }^{2}$, \\ ANESTIS CHARALAMPOPOULOS ${ }^{2}$, NICOLAOS ZAVRAS ${ }^{3}$, DIMITRIOS SOTIROPOULOS ${ }^{2}$, NIKOLAOS KOLIAKOS ${ }^{2}$ \\ ${ }^{1}$ Private practice, Athens, Greece \\ ${ }^{2} 3^{\text {rd }}$ Department of Surgery, Attikon University Hospital, University of Athens School of Medicine, Athens, Greece \\ ${ }^{3}$ Department of Pediatric Surgery, Attikon University Hospital, University of Athens School of Medicine, Athens, Greece
}

\begin{abstract}
Objectives. To present a step by step approach for the diagnosis of adrenal incidentaloma (AI).
Method. An extensive review of the literature was conducted, searching the Pub-Med and Google Scholar using the Mesh terms; Adrenal; Incidentaloma; Adrenal tumours; Radiology; Diagnosis. We also did a cross-referencing search of the literature. Comments on the new European guidelines are presented.

Results. The majority of the tumours are non-functioning benign adenomas. The most important radiological characteristic of an adrenal incidentaloma is the radiation attenuation coefficient. Wash out percentage and the imaging characteristics of the tumour may help in diagnosis.

Conclusion. Density less than $10 \mathrm{HU}$ is in most cases characteristic of a lipid rich benign adenoma. More than $10 \mathrm{HU}$ or/and history of malignancy raise the possibility for cancer. $1 \mathrm{mg}$ dexamethasone test and plasma metanephrines should be done in all patients. If there is history of hypokalemia and/or resistant hypertension we test the plasma aldosterone to plasma renin ratio (ARR). Newer studies have shown that tumours even nonfunctioning and less than $4 \mathrm{~cm}$ may increase the metabolic risks so we may consider surgery at an earlier stage.
\end{abstract}

Key words: Adrenal incidentaloma, Epinephroma, Diagnosis, Radiology, Treatment, ESE guidelines.

\section{INTRODUCTION}

Definition. Adrenal tumours that are discovered "incidentally" during radiology for reasons exclusive of endocrine related symptoms or work up for cancer staging and are larger than $1 \mathrm{~cm}$, are called adrenal incidentalomas (AI) [1-8].

History. Initially it was used the term "incidental adrenal mass" or the term "suprarenal mass". The term "incidentaloma" was coined by professors G. W. Geelhoed and E. M. Druy [8] (personal communication). The term originates from the word "incidental", which according to "Webster's Third New International Dictionary" is "something that is incidental: a subordinate or incidental item" [9]. In 1989 Professor Linos DA suggested the term Adrenaloma [7]. Farrugia F.A. et al., in 2016 [10] proposed the term "Epinephroma" which originates from the Greek word Epinephridion. Epinephridion originates from the Greek words Epi (Eлí = upon

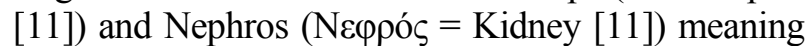
that it is something that it is upon the Kidney. AI is a radiological term.

Etiology. AI are benign or malignant, functioning or non functioning and originate from the cortex or the medulla or they are metastatic [5]. Upon discovery of an AI three questions should be answered. First, is it hormone producing or not, second, is it malignant or benign and if malignant, is it primary or secondary?

Incidence. The incidence of AI varies between $4 \%$ to $5 \%$ of all the abdominal CT and MRI [12-15]. Even though there is no difference between sex or race the incidence of $\mathrm{AI}$ increases as the age increases [16-19].

THE NEW EUROPEAN'S SOCIETY OF ENDOCRINOLOGY, CLINICAL PRACTICE GUIDELINES ON THE MANAGEMENT OF ADRENAL INCIDENTALOMAS [NEGMAI]:

In August, 2016, the European Society of Endocrinology in collaboration with the European Network for the Study of Adrenal Tumors published their recommendations on the management of adrenal incidentalomas [5]. Their guidelines were graded according to the "GRADE" system [Grading of Recommendations Assessment, Development and Evaluation]. They graded 20 of the recommendations/suggestions. Of them 17 were classified as "very low" and three as "low". There were no 
"moderate" or "strong" recommendations/suggestions. They replaced the term "subclinical Cushing's syndrome" (SCS) with a new term that they coined, the term "autonomous cortisol secretion" which applies.

They use this term for patients who do not have any sign or symptom of Cushing's syndrome but who, after overnight $1 \mathrm{mg}$ dexamethasone (DST) their serum cortisol level is higher than $138 \mathrm{nmol} / \mathrm{L}$ (higher than $5 \mu \mathrm{g} / \mathrm{dL}$ ). Surprisingly the NEGMAI do not recommend any testing of ACTH levels, so it seems very odd that they characterize it as "autonomous".

The SCS is much more prevalent than Cushing's syndrome. The prevalence of SCS is between $5-30 \%$ of AI cases and up to $4-7 \%$ of the adult population. So, the SCS prevalence is roughly $0.2-2.0 \%$ in general population [20-22]!

We are going to further comment on these new guidelines in the various steps below.

\section{STEP 1: (Radiology)}

\section{IF AI DISCOVERED BY ULTRASOUNDS OR CT SCAN:}

AI is a radiological term, so the first who discovers and starts examining it is the radiologist. Radiological and biochemical studies are done in parallel and are described in STEPS 1 and 2. We shall describe first the radiological part of the studies and then the biochemical tests. If AI is bilateral we follow the same steps as if it was unilateral [5].

NEGMAI [5] recommend multidisciplinary approach in cases that we are not sure that the lesion is benign, there are symptoms and signs of hormone over production, in cases that the imaging modality showed growth over time and in cases when we consider surgery.

The majority of AI are discovered by either ultrasound or CT scan [23-25]. If AI was discovered by ultrasound then proceed with a CT scan. If AI was discovered by CT scan then proceed examining the following characteristics of CT scan: the radiation attenuation coefficient (density, which is expressed in Hounsfield units (HU)), the imaging characteristics of the tumour and the size of the tumour.

The NEGMAI suggest that if the noncontrast CT is consistent, with what they refer as, "a benign adrenal mass" that is; $(H U \leq 10)$, smaller than $4 \mathrm{~cm}$ and homogeneous, there is no need for further radiology [5]. Contrary to this, in a study done by Song J. H. et al. [26], where they concluded that homogeneous density, can be seen in both benign and malignant lesions. After the intravenous administration of iodinated contrast medium, cancer lesions due to their vascularity enhance avidly. If there was no necrosis the tumor density may be homogeneous [27-30].

If $\mathrm{AI}$ is of a low density $(<10 \mathrm{HU})$, that means that the lipid fraction of the tumour is high, which is characteristic of lipid-rich mild adenomas [6]. Attenuation values of $<10 \mathrm{HU}$ on an unenhanced CT are practically diagnostic for adenomas [27]. Sometimes, though, pheochromocytomas may have density less than $10 \mathrm{HU}$. If $\mathrm{HU}$ is as low as -30 to -100 we diagnose myelolipoma [6]. Myelolipomas and cysts are heterogeneous [12, 23].

Approximately $30 \%$ of adenomas are lipid poor adenomas and they are characterized by high initial density (usually up to $20 \mathrm{HU}$ and in some cases up to $30 \mathrm{HU}$ ) [6]. In that case, density should be assessed before and 1 minute after the administration of i.v. contrast enhancement, followed by acquisition (washout phase) 10 or 15 minutes later. An absolute washout coefficient that is greater than $50 \%$ after 10 minutes, $60 \%$ after 15 minutes and a relative washout coefficient that is greater than $40 \%$ indicates a mild character (benign) of the lesion $[6,27,31,32]$. If washout $<50 \%$ then there is a non adenoma lesion [33].

In NEGMAI, in a flowchart on the management of patients with adrenal incidentalomas (page G14) in case "of potentially malignant" recommend washout $\mathrm{CT}$ as the third option after FDG-PET and MRI. We do not agree with this. We believe that if CT was done without "washout" technique we should proceed with "washout CT" since it gives better results than MRI $[12,14]$. In various studies it was shown that if CT it is not helpful in determining the nature of an AI the MRI cannot confer more information [34].

When an adrenal mass has malignant morphologic features, such as an irregular margin and heterogeneous density with a thick enhancing rim, at presenting contrast-enhanced CT, it likely represents a malignant lesion. Morphologic features that can be seen in both benign and malignant tumours are smooth margins and homogeneous density [26].

Pheochromocytomas have density similar to muscle tissue, that is, approximately 30-40 HU [37]. Sometimes the pheochromocytoma may present with density less than $10 \mathrm{HU}$ and also more than $60 \%$ washout [38].

If size is more than $4 \mathrm{~cm}$ the majority of authors will consider surgical excision $[5,30,39$, 40]. We cannot rely on size to predict malignancy. 
Even from the majority of lesions $\geq 4 \mathrm{~cm}$, the majority [84\%] are benign and lesions less than 4 $\mathrm{cm}$ may be malignant [13].

The available data suggest that nearly all lesions smaller than $4 \mathrm{~cm}$ are benign [41]. The size of the majority of AI remains stable, $5-25 \%$ increases and 3-4\% decreases [41]. Any increase in size should be regarded as malignant until proved otherwise [42]. If the size remains stable it implies benignity $[28,43]$. It is extremely rare for a malignant tumour to remain stable after 6 months of followup imaging $[28,42,43]$.

\section{IF AI DISCOVERED BY MRI:}

An MRI evaluation of the adrenals should usually consist of both $\mathrm{T} 1$ and $\mathrm{T} 2$ weighted images $[44,45]$. Dynamic serial T1 images obtained after intravenous administration of Gd-DTPA are used to show enhancement patterns of adrenal masses [6].

MRI also makes use of the lipid content of adenomas. In-phase and out-of-phase imaging demonstrates a loss of signal in a lipid-rich adenoma, on the out-of phase image compared with the corresponding in-phase imaging. A metastatic deposit does not demonstrate this loss of signal [46].

MRI should be performed in large tumours prior to surgery to assess vascular invasion [47].

Signal intensity within adrenocortical carcinomas and pheochromocytomas is significantly higher and heterogeneous on T1- and especially on T2-weighted images, as well as on Diffusion Weighted Imaging [6]. Pheochromocytoma appears as a "light-bulb" bright lesion on T2- weighted image and has almost the same signal intensity as CSF [48].

If there is suspicion for pheochromocytoma and CT or MRI are not conclusive you may use either I131 MIBG or In111 octreotide [43].

If there is problem in localization of a pheochromocytoma then $18 \mathrm{~F}-\mathrm{DOPA}$ PET is superior to 123I-MIBG scintigraphy and CT/MRI [49].

STEP 2: (History taking, examining the patient and biochemical tests)

In history taking and clinical examination check for, past history of malignancy, since history of malignancy increases the possibility of adrenal metastasis up to $30-50 \%$ [50], high blood pressureespecially resistant hypertension, abdominal obesity but with thin arms and legs, reddish stretch marks in the abdomen, a "moon" face, weak muscles, acne, and fragile skin that heals poorly, flank pain, elevated heart rate, orthostatic hypotension, palpitations, anxiety often resembling that of a panic attack, ephidrosis ( diaphoresis is a misnomer, the correct is ephidrosis (= Greek for sweating)), pallor, weight loss and evidence of sex hormones hypersecretion.

Proceed with the following tests: a $1 \mathrm{mg}$ overnight dexamethasone (DST) suppression test $[5,30,41]$ and plasma metanephrines and urinary fractionated metanephrines [5, 52].

The rationale for the DST suppression test is to detect autonomous cortisol secretion. If positive, then proceed with confirmatory tests [30]. These are: two days $2 \mathrm{mg}$ dexamethasone test, midnight salivary measurement of cortisol (SMC), blood specimen for ACTH, serum and 24-hr urine cortisol [30]. If these are also positive then proceed to surgery after proper preparation.

NEGMAI [5] suggest interpretation of the results of the $1 \mathrm{mg}$ overnight dexamethasone test as a continuous rather than categorical [yes/no] variable and recommend using serum cortisol levels post dexamethasone $\leq 50 \mathrm{nmol} / \mathrm{L}[\leq 1.8 \mu \mathrm{g} / \mathrm{dL}]$ as a diagnostic criterion for the exclusion of autonomous cortisol secretion. They suggest that post-dexamethasone serum cortisol levels between 51 and $138 \mathrm{nmol} / \mathrm{L}$ $(1.9-5.0 \mu \mathrm{g} / \mathrm{dL})$ should be considered as evidence of 'possible autonomous cortisol secretion' and cortisol levels post dexamethasone $>138 \mathrm{nmol} / \mathrm{L}$ $(>5.0 \mu \mathrm{g} / \mathrm{dL})$ should be taken as evidence of 'autonomous cortisol secretion' [5].

They also recommend that for the clinical management of the patient, comorbidities and the age of the patient is of major importance [5]. Concerning confirmatory tests they use the word "might" despite the fact that in the literature until now it has been recommended to proceed with confirmatory tests $[30,53,54]$.

Check also for fasting hyperglycemia, hypokalemia, hyperlipidemia, and leukocytosis with relative lymphopenia [30]. In case of virilization or feminization, check for sex hormones overproduction.

In patients with a history of hypertension, especially resistant and/or hypokalemia, suspect primary aldosteronism (PA) and proceed to measurement of ARR [55]. The definition of resistant hypertension is, when, despite the fact that we use 3 antihypertensive medications, which belong to different classes, concurrently we cannot achieve blood pressure below or equal with the recommendations [56]. ARR is currently the most reliable available means of screening for PA [55]. If this is positive then proceed with one of the four 
confirmatory tests. These are: oral sodium loading, saline infusion test, fludrocortisone suppression test, and captopril challenge [55].

After confirmation of PA proceed with localizing techniques that is adrenal vein sampling (AVS) and/or CT. For cases in which aldosterone producing adenoma (APA) is highly likely (patients $\leq 40$ years of age with marked primary aldosteronism, e.g. PAC $\geq 30 \mathrm{ng} / \mathrm{dL}$ [832 pmol/L] $)$ and a well-defined, hypodense adrenal mass $(>1 \mathrm{~cm}$ on CT scan) is identified, AVS can be bypassed and the patient can undergo unilateral laparoscopic adrenalectomy [57-59].

If plasma metanephrines are more than four times the upper limit the probability of pheochromocytoma is almost $100 \%$ [57]. Significant metanephrine elevations imply epinephrine excess, which localizes tumours to the adrenal medulla [58]. Levels of plasma metanephrines greater than $96 \mathrm{pg} / \mathrm{mL}$ $[59,60]$ are considered abnormal.

If the plasma metanephrines level is less than 4 times the upper limit, we proceed with the clonidine suppression test and measurement of serum catecholamines [61]. We can diagnose pheochromocytoma if after three hours of the clonidine suppression test, the levels of metanephrines are not less than $40 \%$. This test has sensitivity $100 \%$ and specificity $96 \%[62,63]$.

The majority of studies suggest that measurement of plasma free metanephrines is a superior test to $24 \mathrm{~h}$ urinary specimen, for confirming or excluding the diagnosis of pheochromocytoma [52, 57, 64, 65]. Young WF recommends the addition of measurement of fractionated metanephrines and catecholamines in a 24-hr urinary specimen [30] in order to increase the sensitivity by $5 \%$ [66] and is especially helpful in diagnosing patients with dopaminesecreting neoplasms [67].

Radiology does not offer any direct proof of hormone production but may offer an indirect clue if the contralateral adrenal is atrophied [68].

\section{STEP 3A: (DST positive).}

If DST suppression tests and one of the confirmatory tests are positive then after proper preparation proceed to surgery. At least two distinct methods must be abnormal to diagnose Cushing's syndrome.

\section{STEP 3B: (Pheochromocytoma).}

If pheochromocytoma is diagnosed, then check for familial pheochromocytoma syndromes that exist with the pheochromocytoma. These are:
1. MEN type 2 is characterized by unilateral or bilateral pheochromocytoma, medullary thyroid carcinoma, hyperplasia and/or neoplasia of various endocrine tissues. MEN2 has an increased risk for parathyroid adenoma or hyperplasia [69].

2. Von Hippel-Lindau (VHL) syndrome: The diagnosis of VHL is made in individual with renal cell carcinoma, retinal angioma, pheochromocytoma and cerebellar or spinal hemangioblastoma [70].

3. Type 1 neurofibromatosis (NF1). NF1 is characterized by any combination of two of the following: a first-degree family relative with NF1; neurofibromas; intertriginous freckling; Lisch nodules; optic pathway gliomas; cafe-au-lait spots; and distinctive bony lesions [71].

4. Medullary thyroid carcinoma.

So, in case of pheochromocytoma, screen for thyroid, parathyroids, eyes, kidneys and central nervous system diseases.

Then after proper preparation proceed to surgery.

\section{STEP3C: (Primary aldosteronism).}

If ARR is abnormal and a confirmatory test is positive you may proceed with adrenal veins sampling to localize the diseased adrenal. Then if lesion is unilateral, consider surgery and if bilateral start pharmaceutical treatment with a mineralocorticoid receptor antagonist, usually spironolactone.

STEP3D: (Patient with virilization or feminization signs).

NEGMAI suggest measurement of sex hormones and steroid precursors in patients with clinical or imaging features suggestive of adrenocortical carcinoma [5].

\section{STEP 4: (Follow-up).}

If none of the tests is abnormal and the imaging characteristics are not suspicious then, according to NEGMAI, the follow-up of the patient is:

1. In patients with a mass $<4 \mathrm{~cm}$ with clear benign features on imaging studies, no further imaging follow-up.

2. If a patient with indeterminate adrenal mass is not operated, they suggest a non-contrast CT or MRI after 6-12 months to exclude significant growth. They define significant growth as an enlargement by more than $20 \%$ (in addition to at least a $5 \mathrm{~mm}$ increase in maximum diameter) during this period. If the enlargement is less than this, they recommend additional imaging after 6-12 months. 
3. They do not recommend further hormonal work up, if the initial work-up was normal unless new clinical signs of endocrine activity appear or there is worsening of comorbidities.

4. In patients with "autonomous cortisol secretion" without signs of overt Cushing's syndrome, they suggest annual clinical reassessment for cortisol excess comorbidities potentially related to cortisol excess.

\section{DISCUSSION}

CT must be added in all cases that AI was discovered by U/S. Density, imaging characteristics may help in diagnosing AI. In CT, density less than $10 \mathrm{HU}$ indicates, lipid rich adenoma. Pitfall to this may be some cases of pheochromocytoma. Smooth margins and homogeneous density can be seen in both benign and malignant disease. Heterogeneity can be seen in cancer, myelolipoma and adrenal cysts. Myelolipoma has very low density $<(-30)-(-100)$ HU.

Malignant morphologic features are irregular margin and heterogeneous density with a thick enhancing rim, at presenting contrast-enhanced CT. If density is more than $10 \mathrm{HU}$, then proceed with washout CT. If washout is more than $60 \%$ then a diagnosis of an adenoma can be made, if it is less than $50 \%$ then there is a non adenoma lesion.

In MRI we use both $\mathrm{T} 1$ and $\mathrm{T} 2$ weighted sequences. MRI uses intracellular lipids to diagnose adenomas. A benign (lipid-rich) adenoma, in chemical shift MRI, loses its signal on out of phase comparing to its in phase images and to reference organs that contain fat [72]. MRI should be performed in large tumours prior to surgery to assess vascular invasion.

If there is suspicion for pheochromocytoma and $\mathrm{CT}$ or MRI are not conclusive you may use either I131 MIBG or In111 octreotide [43]. If there is problem in localization of a pheochromocytoma then 18F-DOPA PET is superior to 123I-MIBG scintigraphy and CT/MRI [49].

Nevertheless the imaging characteristics always proceed with DST and plasma metanephrines and if the patient has a history of hypertension, especially if it is treatment resistant check for PA and do ARR test. If $1 \mathrm{mg}$ dexamethasone or ARR are positive then we proceed with confirmatory tests. If DST and confirmatory tests are positive then after proper preparation proceed with surgery. In case ARR and confirmatory test are positive, if lesion is unilateral then proceed with surgery otherwise administer spironolactone.
For tumours more than $4 \mathrm{~cm}$ an adrenalectomy is recommended by the majority of authors $[16,30,41]$. As the size of an $\mathrm{AI}$ increases, increase and the risk for cancer and increase the chances for "autonomous cortisol secretion" [73, 74].

NEGMAI recommend screening patients with "autonomous cortisol secretion" for asymptomatic vertebral fractures. The panel did not reach consensus on recommending assessment of bone mineral density by dual-energy $\mathrm{x}$-ray absorptiometry [5]. Osteoporosis precedes vertebral fractures, so we believe that it would be reasonable to start from checking bone density at the start up tests.

The NEGMAI recommendations received almost immediately critics. Morelli V., et al. [20], in a study they published almost immediately after the NEGMAI was published, suggest biochemical and morphological tests for all patients for at least 5 years, even if the mass is $<4 \mathrm{~cm}$ and with benign imaging characteristics and non functioning. This is in accordance with the guidelines $[16,41]$ before NEGMAI.

Lopez D., et al. [78], in their study found that nonfunctioning adrenal tumors [NFAT] had significantly higher risk for incident composite diabetes than those without adrenal tumors and that higher "normal" post-dexamethasone serum cortisol $\leq 50 \mathrm{nmol} / \mathrm{L}$ was associated with bigger nonfunctioning $\mathrm{AI}$ and higher incidence of T2D. In a similar study, Papanastasiou L., et al. [79] concluded that after mean follow-up $5.54 \pm 1.7$ years patients with NFAT were at greater risk of deteriorating of metabolic parameters. Salcuni A.F., et al. in patients with monolateral $\mathrm{AI}$ and $\mathrm{SH}$, adrenalectomy reduces the risk of vertebral fractures [80].

Tuna M.M., et al. [81], studied the incidence of various cardiometabolic risk factors in patients with $\mathrm{AI}$ and they concluded that there is increasing evidence that several cardiometabolic risk factors occur with higher prevalence in non-functioning adrenal incidentaloma patients compared to agematched healthy subjects. In their study, hypertension prevalence and carotid intima media thickness were higher in the NFAT group.

Actually these studies prove that it is not only risky if we follow the NEGMAI and stop following up a patient with NFAT but we may have to consider surgery even in cases of NFAT. Ye Y. L., et al. [82] in their study 634 patients with adrenal incidentaloma, they concluded that except of followup, we may consider laparoscopic adrenalectomy for small AI. 
The NEGMAI define as a limit after $1 \mathrm{mg}$ dexamethasone, $1.8 \mu \mathrm{g} / \mathrm{dL}$ for exclusion of "autonomous cortisol secretion" despite the fact that Morelli V., et al. in their study proved that the cut off of $1.5 \mu \mathrm{g} / \mathrm{dL}$ showed the best sensitivity for predicting the cardiovascular events in AI patients [77], this also is in accordance with the study of Lopez D., et al. [78].

Fontana D., et al., evaluating the role of ultrasonography [U/S] in the follow-up of adrenal incidentalomas, found that at diagnosis, U/S was not sufficiently reliable in evaluating adrenal mass characteristics. Considering the high correlation between U/S and CT size estimation, in the case of a presumably benign lesion, U/S could be considered a simple, economic, and effective method of follow-up, with CT limited to evaluating masses growing over time (CT remains mandatory at diagnosis) [83].

Having regard to the above study we agree with Morelli V., et al. [20], who suggest that for all patients with initially apparent benign adrenal mass, a morphological follow-up is needed for at least 5 years and that after the initial CT in the first 6-12 months after the initial diagnosis, the subsequent follow-up could be performed every 2-3 years by an ultrasound evaluation, with the CT scan being reserved in case of suspected growth at the ultrasound imaging.

We feel that it is somehow risky to follow the NEGMAI and that it is safer to follow the recommendations of the American Association of Clinical Endocrinologists and American Association of Endocrine Surgeons (AACE, AAES) [16] or the NIH [41].

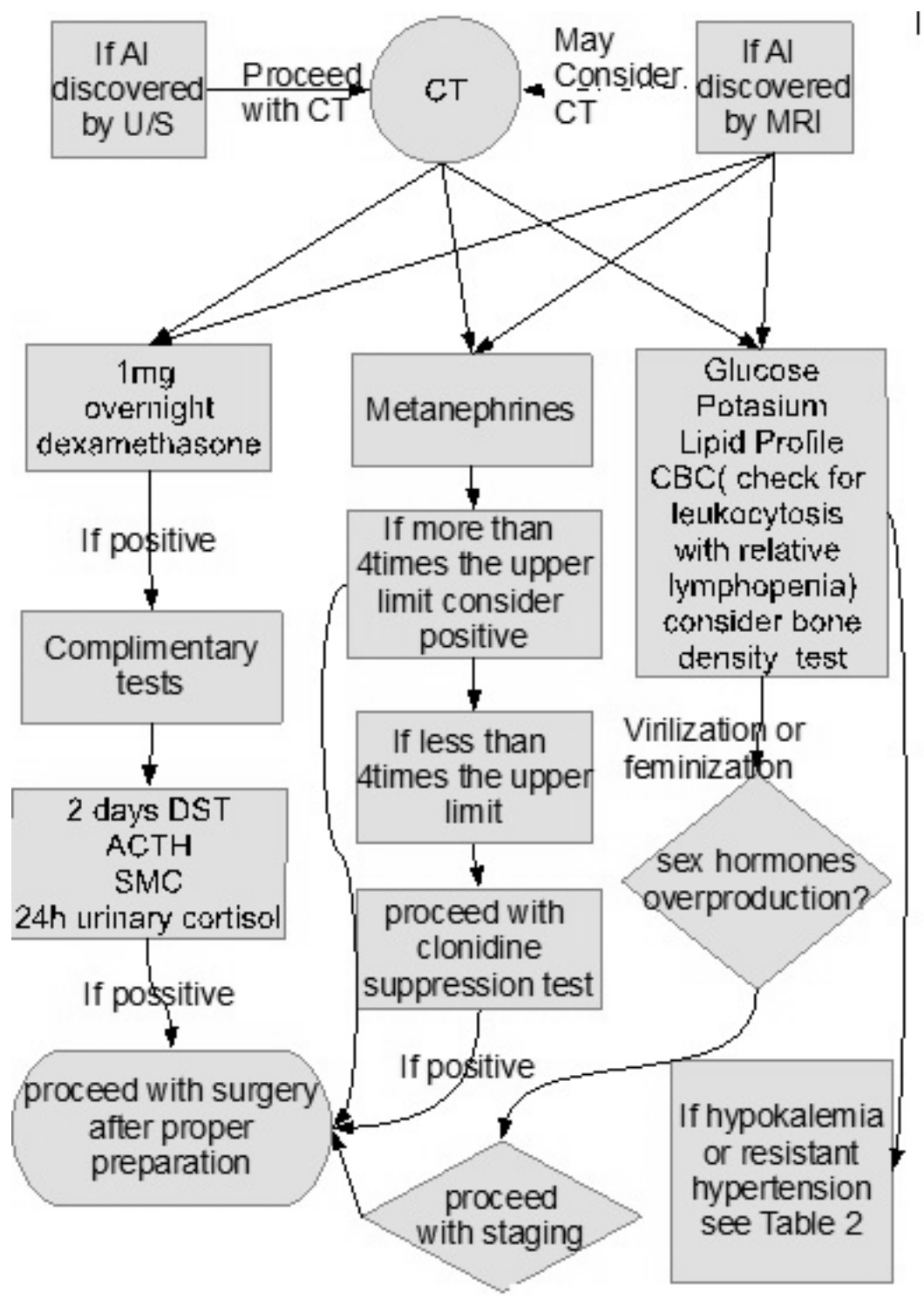

Figure 1. Algorithm for diagnosing AI (SMC = Salivary measurement of cortisol. $\mathrm{CBC}=$ complete blood count. 


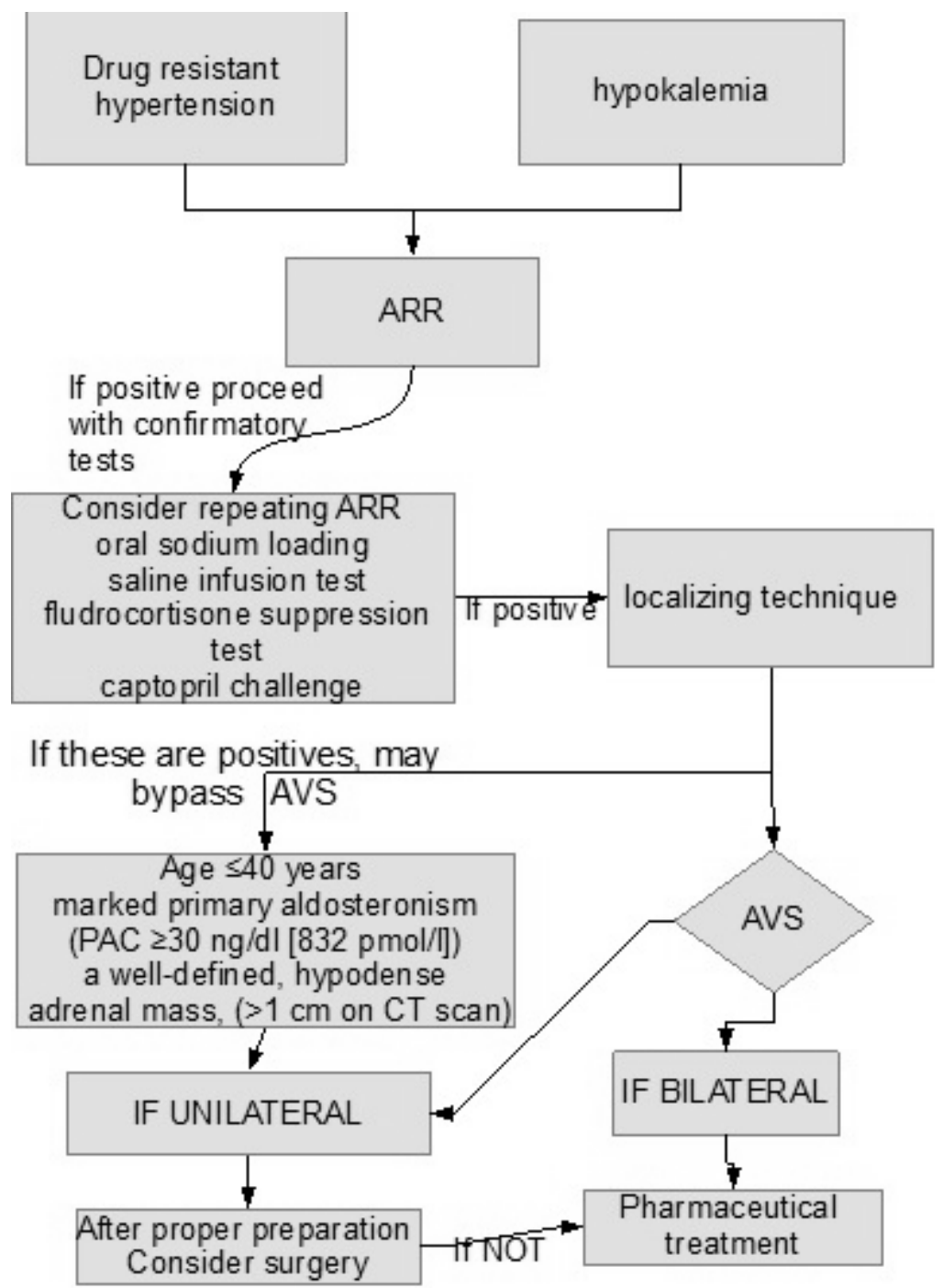

Figure 2. Flow chart on managing AI and resistant hypertension and/or hypokalemia.

Drug resistant hypertension $=$ is defined as blood pressure that remains above goal in spite of the concurrent use of 3 antihypertensive agents of different classes. $\mathrm{ARR}=$ plasma aldosterone renin ratio. $\mathrm{AVS}=$ adrenal vein sampling.

AACE and AAES recommendations on follow-up of patients with AI are:

1) AI less than $4 \mathrm{~cm}$ and imaging characteristics relevant with benign adrenal adenoma should have CT scan after 3 to 6 months and then after every year for five years.

2) Biochemical tests for hormone evaluation should be done annually for five years.

3) The risk of an AI to increase in size is from $6 \%$ to $29 \%$ on the fifth year.

4) The risk of an AI to become hormonally active is from $17 \%$ to $47 \%$ on the fifth year.

5) If a tumor increases in size or becomes hormonally active surgery should be considered.

6) In patients with pheochromocytoma follow-up should be done for the rest of the life as $10-15 \%$ recur.
Questions that should be addressed in future research:

1. If after long term (more than 5 years) AI may become malignant.

2. If we have to perform impaired glucose tolerance, test at the initial test and/or in the follow-up.

3. If we have to perform bone density test at the initial tests.

4. If we have to consider surgery at an earlier stage.

5. After how long it is safe to stop following-up patients with AI.

6. If $\mathrm{U} / \mathrm{S}$ is safe as a follow-up modality.

7. If it is prudent to perform ARR test at the initial biochemical tests, given the fact that primary aldosteronism is the most frequent cause of secondary hypertension and its prevalence is increasing [84]. 
Declaration of interest: The author declares that there is no conflict of interest that could be perceived as prejudicing the impartiality of the research reported.
Funding: This research did not receive any specific grant from any funding agency in the public, commercial or not-for-profit sector.

Obiective. Prezentarea unei abordări pas cu pas pentru diagnosticul incidentalomului adrenal (AI).

Metode. A fost realizată o căutare extensivă a literaturii de specialitate în PubMed şi Google Scholar fiind folosite cuvintele cheie din Mesh: Adrenal; Incidentaloma; Adrenal tumours; Radiology; Diagnosis. Au fost făcute şi comentarii pe marginea noilor ghiduri europene in acest domeniu.

Rezultate. Majoritatea tumorilor sunt adenoame benigne. Caracteristica radiologică a unui incidentalom este coeficientul de atenuare radiologică. Caracteristicile imagistice pot ajuta diagnosticul.

Concluzii. Densitatea mai mică de $10 \mathrm{HU}$ este caracteristică unui adenom bogat în lipide.O densitate mai mare de $10 \mathrm{HU}$ sau istoric de malignitate creşte posibilitatea cancerului. Dozarea metanefrinelor plasmatice şi testul cu stimulare la dezametazonă trebuie realizat la toți pacienții. Dacă există istoric de episoade cu hipokaliemie sau de episoade cu pusee hipertensive se testează nivelurile raportului aldosteronului plasmatic/renina plasmatică. Studii recente au demonstrat că tumorile non-funcționale şi mai mici de $4 \mathrm{~cm}$ pot creşte riscul metabolic şi astfel că putem considera intervenția terapeutică chirurgicală timpurie.

Correspondence to: Frederick-Anthony Farrugia, MD

Demergi 6, Athens, 10445, Greece.

Telephone/fax: 2108328214.

E-mail: farrugiafa@gmail.com

\section{REFERENCES}

1. UDELSMAN R. ADRENAL. In: Norton A J, Bollinger RR, editors. Surgery, Basic Science and Clinical Evidence: Springer; 2001, p. 902.

2. BULOW B, JANSSON S, JUHLIN C, STEEN L, THOREN M, WAHRENBERG H, et al. Adrenal incidentaloma-follow-up results from a Swedish prospective study. Eur J Endocrinol 2006; 154 (3):419-23.

3. ANAGNOSTIS P, KARAGIANNIS A, TZIOMALOS K, KAKAFIKA AI, ATHYROS VG, MIKHAILIDIS DP. Adrenal incidentaloma: a diagnostic challenge. Hormones (Athens) 2009; 8 (3):163-84.

4. GRUMBACH MM, BILLER BM, BRAUNSTEIN GD, CAMPBELL KK, CARNEY JA, GODLEY PA, et al. Management of the clinically inapparent adrenal mass (adrenal incidentaloma). Annals of Internal Medicine 2003; 138 (5):424-429.

5. FASSNACHT M, ARLT W, BANCOS I, DRALLE H, NEWELL-PRICE J, SAHDEV A, et al. Management of adrenal incidentalomas: European society of endocrinology clinical practice guideline in collaboration with the European network for the study of adrenal tumors. European Journal of Endocrinology 2016; 175 (2):G1-G34.

6. PAPIERSKA L, CICHOCKI A, SANKOWSKI AJ, CWIKLA JB. Adrenal incidentaloma imaging - the first steps in therapeutic management. Pol J Radiol 2013; 78 (4):47-55.

7. LINOS DA. Adrenal incidentaloma (adrenaloma). Hormones (Athens) 2003; 2 (1):12-21.

8. GEELHOED GW, DRUY EM. Management of the adrenal "incidentaloma". Surgery 1982; 92 (5):866-74.

9. GOVE PB. Webster's third new international dictionary of the English language, unabridged: Merriam-Webster; 2002.

10. FARRUGIA FA, MARTIKOS G, TZANETIS P, ZAVRAS N, CHARALAMPOPOULOS A, SOTIROPOULOS D, et al. Adrenal incidentaloma or epinephroma and review of the literature. Differential Diagnosis of Adrenal Incidentaloma. Khirurgiia 2016; October (3):120-129.

11. DIVRY DBC. English-Greek and Greek English Handy Dictionary. In Revised Edition ed. New York: D.C. Divry, Inc., Publishers; 1994, p. 326.

12. WARDA MHA, SHEHATA SM, ZAITON F. Chemical-shift MRI versus washout CT for characterizing adrenal incidentalomas. Clinical Imaging 2016; 40 (4):780-787.

13. YIP L, TUBLIN ME, FALCONE JA, NORDMAN CR, STANG MT, OGILVIE JB, et al. The adrenal mass: correlation of histopathology with imaging. Annals of surgical oncology 2010; 17 (3):846-852. 
14. SEO JM, PARK BK, PARK SY, KIM CK. Characterization of lipid-poor adrenal adenoma: chemical-shift MRI and washout CT. American Journal of Roentgenology 2014; 202 (5):1043-1050.

15. SCHIEDA N, SIEGELMAN ES. Update on CT and MRI of Adrenal Nodules. American Journal of Roentgenology 2017:1-12.

16. ZEIGER MA, THOMPSON GB, DUH Q-Y, HAMRAHIAN AH, ANGELOS P, ELARAJ D, et al. American Association of Clinical Endocrinologists and American Association of Endocrine Surgeons medical guidelines for the management of adrenal incidentalomas. Endocrine Practice 2009; 15:1-20.

17. DEFECHEREUX T, DEGAUQUE C, HAMOIR E, LAMBERTY G, PREUD'HOMME L, MEURISSE M. [Discordance between actual and radiologically estimated size of an incidentaloma. Delay in questions regarding operative decision-making criteria]. Ann Chir 2002; 127 (2):126-9.

18. PAPIERSKA L, CICHOCKI A, SANKOWSKI AJ, CWIKLA JB. Adrenal incidentaloma imaging - the first steps in therapeutic management. Pol J Radiol; 78 (4):47-55.

19. REGINELLI A, DI GREZIA G, IZZO A, DB€ $€^{\mathrm{TM}}$ ANDREA A, GATTA G, CAPPABIANCA S, et al. Imaging of adrenal incidentaloma: Our experience. International Journal of Surgery 2014; 12:S126-S131.

20. MORELLI V, SCILLITANI A, AROSIO M, CHIODINI I. Follow-up of patients with adrenal incidentaloma, in accordance with the European Society of Endocrinology guidelines: Could we be safe? Journal of Endocrinological Investigation 2016:1-3.

21. CHIODINI I, ALBANI A, AMBROGIO AG, CAMPO M, DE MARTINO MC, MARCELLI G, et al. Six controversial issues on subclinical Cushing's syndrome. Endocrine 2016:1-5.

22. CHIODINI I, MORELLI V. Subclinical hypercortisolism: how to deal with it? In: Cortisol Excess and Insufficiency: Karger Publishers; 2016, 28-38.

23. PAPIERSKA L, CICHOCKI A, SANKOWSKI AJ, CWIKLA JB. Adrenal incidentaloma imaging-the first steps in therapeutic management. Polish Journal of Radiology 2013; 78 (4):47.

24. MANTERO F, TERZOLO M, ARNALDI G, OSELLA G, MASINI AM, ALI A, et al. A survey on adrenal incidentaloma in Italy. Study Group on Adrenal Tumors of the Italian Society of Endocrinology. J Clin Endocrinol Metab 2000; 85 (2):637-44.

25. TABUCHI Y, OTSUKI M, KASAYAMA S, KOSUGI K, HASHIMOTO K, YAMAMOTO T, et al. Clinical and endocrinological characteristics of adrenal incidentaloma in Osaka region, Japan. Endocrine journal 2015 (0).

26. SONG JH, GRAND DJ, BELAND MD, CHANG KJ, MACHAN JT, MAYO-SMITH WW. Morphologic features of 211 adrenal masses at initial contrast-enhanced CT: can we differentiate benign from malignant lesions using imaging features alone? American Journal of Roentgenology 2013; 201 (6):1248-1253.

27. ILIAS I, SAHDEV A, REZNEK RH, GROSSMAN AB, PACAK K. The optimal imaging of adrenal tumours: a comparison of different methods. Endocrine-Related Cancer 2007; 14 (3):587-599.

28. DUNNICK NR, KOROBKIN M. Imaging of adrenal incidentalomas: current status. American Journal of Roentgenology 2002; 179 (3):559-568.

29. LOCKHART ME, SMITH JK, KENNEY PJ. Imaging of adrenal masses. European journal of radiology 2002; 41 (2):95-112.

30. YOUNG JR WF. The incidentally discovered adrenal mass. New England Journal of Medicine 2007; 356 (6):601-610.

31. ZEIGER MA, SIEGELMAN SS, HAMRAHIAN AH. Medical and surgical evaluation and treatment of adrenal incidentalomas. The Journal of Clinical Endocrinology \& Metabolism 2011; 96 (7):2004-2015.

32. MANSMANN G, LAU J, BALK E, ROTHBERG M, MIYACHI Y, BORNSTEIN SR. The clinically inapparent adrenal mass: update in diagnosis and management. Endocrine reviews 2004; 25 (2):309-340.

33. BEDNARCZUK T, BOLANOWSKI M, SWORCZAK K, GORNICKA B, CIESZANOWSKI A, OTTO M, et al. Adrenal incidentaloma in adults' management recommendations by the Polish Society of Endocrinology. Endokrynologia Polska 2016; $67(2): 234$.

34. FRANCIS IR. Distinguishing benign from malignant adrenal masses. Cancer Imaging 2015; 3 (2):102.

35. MAYO-SMITH W, LEE M, MCNICHOLAS M, HAHN P, BOLAND G, SAINI S. Characterization of adrenal masses $(<5 \mathrm{~cm})$ by use of chemical shift MR imaging: observer performance versus quantitative measures. AJR. American Journal of Roentgenology 1995; 165 (1):91-95.

36. BILBEY JH, MCLOUGHLIN R, KURKJIAN P, WILKINS G, CHAN N, SCHMIDT N, et al. MR imaging of adrenal masses: value of chemical-shift imaging for distinguishing adenomas from other tumors. AJR. American Journal of Roentgenology 1995; 164 (3):637-642.

37. MIYAKE H, MAEDA H, TASHIRO M, SUZUKI K, NAGATOMO H, AIKAWA H, et al. CT of adrenal tumors: frequency and clinical significance of low-attenuation lesions. American Journal of Roentgenology 1989; 152 (5):1005-1007.

38. BLAKE MA, KRISHNAMOORTHY SK, BOLAND GW, SWEENEY AT, PITMAN MB, HARISINGHANI M, et al. Lowdensity pheochromocytoma on CT: a mimicker of adrenal adenoma. American Journal of Roentgenology 2003; 181 (6):1663-1668.

39. ARNALDI G, MASINI A, GIACCHETTI G, TACCALITI A, FALOIA E, MANTERO F. Adrenal incidentaloma. Brazilian Journal of Medical and Biological Research 2000; 33 (10):1177-1189.

40. LOU I, SCHNEIDER DF, LEVERSON GE, SIPPEL RS, CHEN H. Do additional imaging studies change operative management in patients undergoing adrenalectomy? Surgery 2015; 158 (4):1003-1011.

41. NIH state-of-the-science statement on management of the clinically inapparent adrenal mass ("incidentaloma"). NIH Consens State Sci Statements 2002; 19 (2):1-25.

42. BOLAND GW, BLAKE MA, HAHN PF, MAYO-SMITH WW. Incidental Adrenal Lesions: Principles, Techniques, and Algorithms for Imaging Characterization 1. Radiology 2008; 249 (3):756-775.

43. MAYO-SMITH WW, BOLAND GW, NOTO RB, LEE MJ. State-of-the-art adrenal imaging. Radiographics 2001; 21 (4):995-1012.

44. LEE JK. Computed body tomography with MRI correlation: Lippincott Williams \& Wilkins, 1998. 
45. KRESTIN GP, STEINBRICH W, FRIEDMANN G. Adrenal masses: evaluation with fast gradient-echo MR imaging and GdDTPA-enhanced dynamic studies. Radiology 1989; 171 (3):675-680.

46. CONDER G, RENDLE J, KIDD S, MISRA RR. AZ of Abdominal Radiology. Cambridge University Press; 2009. p. 28-37.

47. SCHTEINGART D, DOHERTY G, GAUGER P, GIORDANO T, HAMMER G, KOROBKIN M, et al. Management of patients with adrenal cancer: recommendations of an international consensus conference. Endocrine-Related Cancer 2005; 12 (3):667-680.

48. ELSAYES KM, MUKUNDAN G, NARRA VR, LEWIS JR JS, SHIRKHODA A, FAROOKI A, et al. Adrenal Masses: MR Imaging Features with Pathologic Correlation 1. Radiographics 2004; 24 (suppl_1):S73-S86.

49. FIEBRICH H-B, BROUWERS AH, KERSTENS MN, PIJL ME, KEMA IP, DE JONG JR, et al. 6-[F-18] Fluoro-Ldihydroxyphenylalanine positron emission tomography is superior to conventional imaging with 123I-metaiodobenzylguanidine scintigraphy, computer tomography, and magnetic resonance imaging in localizing tumors causing catecholamine excess. The Journal of Clinical Endocrinology \& Metabolism 2009; 94 (10):3922-3930.

50. SUNDIN A. Imaging of adrenal masses with emphasis on adrenocortical tumors. Theranostics 2012; 2 (5):516-22.

51. Dorland. Dorland's Illustrated Medical Dictionary. 32 ed: Saunders, 2007.

52. LENDERS JW, PACAK K, WALTHER MM, LINEHAN WM, MANNELLI M, FRIBERG P, et al. Biochemical diagnosis of pheochromocytoma: which test is best? Jama 2002; 287 (11):1427-1434.

53. IACOBONE M, CITTON M, SCARPA M, VIEL G, BOSCARO M, NITTI D. Systematic review of surgical treatment of subclinical Cushing's syndrome. British Journal of Surgery 2015; 102 (4):318-330.

54. THOMAS AZ, BLUTE ML, SEITZ C, HABRA MA, KARAM JA. Management of the incidental adrenal mass. European Urology Focus 2016; 1 (3):223-230.

55. FUNDER JW, CAREY RM, FARDELLA C, GOMEZ-SANCHEZ CE, MANTERO F, STOWASSER M, et al. Case detection, diagnosis, and treatment of patients with primary aldosteronism: an endocrine society clinical practice guideline. The Journal of Clinical Endocrinology \& Metabolism 2008; 93 (9):3266-3281.

56. CALHOUN DA, JONES D, TEXTOR S, GOFF DC, MURPHY TP, TOTO RD, et al. Resistant hypertension: diagnosis, evaluation, and treatment. Circulation 2008; 117 (25):e510-e526.

57. MATTSSON C, YOUNG WF. Primary aldosteronism: diagnostic and treatment strategies. Nature Clinical Practice Nephrology 2006; 2 (4):198-208.

58. YOUNG WF, JR. Minireview: primary aldosteronism--changing concepts in diagnosis and treatment. Endocrinology $2003 ; 144$ (6):2208-13.

59. YOUNG JR WF. Adrenalectomy for primary aldosteronism; authors' reply. Ann Intern Med 2003; 138:157-159.

60. EISENHOFER G, LENDERS JW, LINEHAN WM, WALTHER MM, GOLDSTEIN DS, KEISER HR. Plasma normetanephrine and metanephrine for detecting pheochromocytoma in von Hippel-Lindau disease and multiple endocrine neoplasia type 2. New England Journal of Medicine 1999; 340 (24):1872-1879.

61. GALATI S-J, SAID M, GOSPIN R, BABIC N, BROWN K, GEER EB, et al. The mount Sinai clinical pathway for the management of pheochromocytoma. Endocrine Practice 2014; 21 (4):368-382.

62. FRANCIS IR, GROSS MD, SHAPIRO B, KOROBKIN M, QUINT L. Integrated imaging of adrenal disease. Radiology 1992; 184 (1):1-13.

63. FRANCIS IR, KOROBKIN M, BRODEUR FJ, YUTZY GG, QUINT LE, DUNNICK NR, et al. Pheochromocytoma Differentiation of adrenal adenomas from nonadenomas using CT attenuation values. Radiol Clin North Am 1996; 34 (6):1101-12.

64. EISENHOFER G, GOLDSTEIN DS, WALTHER MM, FRIBERG P, LENDERS JW, KEISER HR, et al. Biochemical diagnosis of pheochromocytoma: how to distinguish true-from false-positive test results. The Journal of Clinical Endocrinology \& Metabolism 2003; 88 (6):2656-2666.

65. VAN BERKEL A, LENDERS J, TIMMERS H. Diagnosis of endocrine Disease: Biochemical diagnosis of phaeochromocytoma and paraganglioma. European Journal of Endocrinology 2014; 170 (3):R109-R119.

66. MAUREA S, CUOCOLO A, REYNOLDS J, NEUMANN R, SALVATORE M. Diagnostic imaging in patients with paragangliomas. Computed tomography, magnetic resonance and MIBG scintigraphy comparison. The quarterly journal of nuclear medicine: official publication of the Italian Association of Nuclear Medicine (AIMN) [and] the International Association of Radiopharmacology (IAR) 1996; 40 (4):365-371.

67. RABER W, RAFFESBERG W, BISCHOF M, SCHEUBA C, NIEDERLE B, GASIC S, et al. Diagnostic efficacy of unconjugated plasma metanephrines for the detection of pheochromocytoma. Archives of Internal Medicine 2000; 160 (19):2957-2963.

68. MITTENDORF EA, EVANS DB, LEE JE, PERRIER ND. Pheochromocytoma: advances in genetics, diagnosis, localization, and treatment. Hematology/oncology clinics of North America 2007; 21 (3):509-525.

69. YOUNG WF. Primary aldosteronism: renaissance of a syndrome. Clinical endocrinology 2007; 66 (5):607-618.

70. SAWKA AM, JAESCHKE R, SINGH RJ, YOUNG JR WF. A comparison of biochemical tests for pheochromocytoma: measurement of fractionated plasma metanephrines compared with the combination of 24-hour urinary metanephrines and catecholamines. The Journal of Clinical Endocrinology \& Metabolism 2003; 88 (2):553-558.

71. JOHNSON PT, HORTON KM, FISHMAN EK. Adrenal Mass Imaging with Multidetector CT: Pathologic Conditions, Pearls, and Pitfalls 1. Radiographics 2009; 29 (5):1333-1351.

72. MARINI F, FALCHETTI A, DEL MONTE F, CARBONELL SALA S, TOGNARINI I, LUZI E, et al. Multiple endocrine neoplasia type 2. Orphanet J Rare Dis 2006; 1 (45):4.

73. ERLIC Z, NEUMANN HP. Familial pheochromocytoma. Hormones (Athens) 2009; 8 (1):29-38.

74. National Institutes of Health Consensus Development Conference Statement: neurofibromatosis. Bethesda, Md., USA, July 13-15, 1987. Neurofibromatosis 1988; 1 (3):172-8. 
75. HERR K, MUGLIA VF, KOFF WJ, WESTPHALEN AC. Imaging of the adrenal gland lesions. Radiologia brasileira $2014 ; 47$ (4):228-239.

76. BARZON L, SCARONI C, SONINO N, FALLO F, PAOLETTA A, BOSCARO M. Risk factors and long-term follow-up of adrenal incidentalomas. J Clin Endocrinol Metab 1999; 84 (2):520-6.

77. MORELLI V, REIMONDO G, GIORDANO R, DELLA CASA S, POLICOLA C, PALMIERI S, et al. Long-term follow-up in adrenal incidentalomas: an Italian multicenter study. The Journal of Clinical Endocrinology \& Metabolism 2014; 99 (3):827-834.

78. LOPEZ D, LUQUE-FERNANDEZ MA, STEELE A, ADLER GK, TURCHIN A, VAIDYA A. "Nonfunctional” Adrenal Tumors and the Risk for Incident Diabetes and Cardiovascular Outcomes. A Cohort Study "Nonfunctional" Adrenal Tumors and Risk for Incident Diabetes. Annals of internal medicine 2016; 165 (8):533-542.

79. PAPANASTASIOU L, ALEXANDRAKI KI, ANDROULAKIS, II, FOUNTOULAKIS S, KOUNADI T, MARKOU A, et al. Concomitant alterations of metabolic parameters, cardiovascular risk factors and altered cortisol secretion in patients with adrenal incidentalomas during prolonged follow-up. Clin Endocrinol (Oxf); 86 (4):488-498.

80. SALCUNI AS, MORELLI V, VAINICHER CE, PALMIERI S, CAIROLI E, SPADA A, et al. Adrenalectomy reduces the risk of vertebral fractures in patients with monolateral adrenal incidentalomas and subclinical hypercortisolism. European Journal of Endocrinology 2016; 174 (3):261-269.

81. TUNA MM, IMGA NN, DOGAN BA, YILMAZ FM, TOPCUOGLLU C, AKBABA G, et al. Non-functioning adrenal incidentalomas are associated with higher hypertension prevalence and higher risk of atherosclerosis. Journal of endocrinological investigation 2014; 37 (8):765-768.

82. YE Y-L, YUAN X-X, CHEN M-K, DAI Y-P, QIN Z-K, ZHENG F-F. Management of adrenal incidentaloma: the role of adrenalectomy may be underestimated. BMC surgery 2016; 16 (1):41.

83. FONTANA D, PORPIGLIA F, DESTEFANIS P, FIORI C, ALI A, TERZOLO M, et al. What is the role of ultrasonography in the follow-up of adrenal incidentalomas? Urology 1999; 54 (4):612-616.

84. MULATERO, P., RABBIA F, MILAN A, PAGLIERI C, MORELlO F, CHIANDUSSI L, VEGLIO F. Drug effects on aldosterone/plasma renin activity ratio in primary aldosteronism. Hypertension 2002; 40 (6):897-902.

Received May 3, 2017 